\author{
EMILIA BAŃCZYK \\ (D) https://orcid.org/ 0000-0002-6155-2701 \\ Uniwersytet Śląski \\ Katowice
}

\title{
O roli języka \\ w kształtowaniu tożsamości młodego pokolenia
}

The role of language in shaping the young generation's identity

\begin{abstract}
The author addresses the constantly relevant problem of the relationship between language and identity, gaining a new dimension in the context of transformations related to civilisation, globalisation and glocalisation. The research concerned students' awareness of the role they believed language to play in the shaping of identity. For this purpose, surveys were conducted among 66 students of humanities. The paper fits in the field of ethnolinguistics and sociolinguistics.
\end{abstract}

Key words: identity, ethnolinguistics, sociolinguistics, language

Używanie języka to wychodzenie z domu.

Zbigniew Kadłubek

Duch języka objawia się najwyraźniej w jego nieprzetłumaczalnych słowach.

Marie von Ebner-Eschenbach

\section{Tożsamość: źródła sensu}

Tożsamość jako pojęcie interdyscyplinarne występuje we wszystkich naukach, które interesują się człowiekiem¹. Tożsamość odnosi się do odpowiedzi na pytania: kim jestem, kim się staję, a także kto mówi, kto działa, i jako pojęcie dialektyczne istnieje w opozycji do tego, co odmienne, do wartości,

\footnotetext{
${ }^{1}$ Szczególnie bogatą tradycję ma w filozofii, psychologii i socjologii (por. np. Karkowska 2013).
} 
z którymi się nie identyfikuję - tożsamość oznacza zatem, że „jestem identyczny ze sobą i różny od innych”. Gdy zajmujemy się tym zagadnieniem, przedmiotem badania nie jest właściwie sama tożsamość, a sposoby jej doświadczania, czyli poczucie tożsamości, to jak jest postrzegana, myślana i przeżywana przez ludzi (Karkowska 2013, 59). Tożsamość umożliwia identyfikację znaczeń przez jednostkę i kształtowanie jej systemu wartości. Składają się na nią poczucie stałości, spójności, odrębności od otoczenia i posiadania wewnętrznej treści (Cybal-Michalska 2005, 93; Karkowska 2013, 85). Badacze wyróżniaja dwa podstawowe rodzaje tożsamości: s połeczna, czyli „sposób określania samego siebie poprzez przynależność do różnych grup społecznych" (Nowicka 1992) i ind yw id u a lna a osobista.

Poczucie tożsamości społecznej odnosi się do wszystkich identyfikacji człowieka, które związane są z przynależnością do różnych grup, zaś poczucie tożsamości osobistej dotyczy tych kategorii, które opisuja jego indywidualne właściwości, odrębność i wyjątkowość (Jaworska 2012, 17).

Wielu badaczy opisuje tożsamość jako proces samookreślenia, proces „stawania się i wyboru siebie, proces, który spaja i integruje różnorodne cząstkowe identyfikacje w coś, co jest czymś więcej niż ich prostą sumą" (Jawłowska 2001, 55). Przytoczona charakterystyka tożsamości wydaje się spójna ze stanowiskiem narratywistów, następców Martina Heideggera, którzy uznają, że tożsamość człowieka ma strukturę narracji widzianej od wewnątrz, z punktu widzenia bohatera („tożsamość jednostki jest tożsamością jej narracji o sobie”, „póki jednostka żyje, nie jest ona ostateczna”, por. Rosner 1999, 14; Lubas-Bartoszyńska 2003, 141). Owa narracja nie jest utkana jedynie $z$ własnych przeżyć podmiotu, ale również, a może przede wszystkim, jak chciałby Wittgenstein, ze „zbiorowego doświadczenia społeczności czy kultury, której jest uczestnikiem” (Rosner 2006, 22, za: Konieczna 2014, 53).

Tożsamość kształtuje się w procesach socjalizacji pierwotnej i wtórnej, a więc przez całe życie jednostki². Jej formowanie według Görana Therborna zakłada różnicowanie, krystalizowanie własnego wizerunku i rozpoznawanie go przez innych (Therborn 1998, 351; więcej zob. Kałuzińska 2017).

Zdaniem Anthony'ego Giddensa

2 Por.: „Kształtowanie tożsamości nie zaczyna się ani nie kończy się wraz z dorastaniem, jest procesem trwającym całe życie, i to w znacznym stopniu nieświadomym dla jednostki i społeczeństwa” (Witkowski 2000, 100). 
tożsamość ogólnie odnosi się do tego, jak ludzie rozumieją sami siebie i co ma dla nich znaczenie. Takie rozumienie wykształca się w odniesieniu do pewnych cech, które maja pierwszeństwo nad innymi źródłami sensu. Do najważniejszych źródeł tożsamości należą: płeć, orientacja seksualna, narodowość lub etniczność i klasa społeczna3 (Giddens 2007, 52; por. Kałuzińska 2017).

Jerzy Szacki z kolei uznaje, że aby określić tożsamość danej zbiorowości, należy

zajmować się językiem, jakim posługują się jej członkowie, tym, jak się organizują jakie mają obyczaje i zamiłowania kulinarne, budownictwo, używki i sposoby spędzania wolnego czasu, nazwy ulic, ikonografię, ulubione sporty, metody wychowywania dzieci i układ stosunków między pokoleniami, formy kultu religijnego, oraz wieloma innymi przedmiotami wrzucanymi do olbrzymiego pojęciowego worka zwanego pospolicie kulturą (Szacki 2004, 24).

Obiektywny wyznacznik tożsamości zbiorowej stanowi zatem jej kultura, subiektywny zaś to świadomość zbiorowości w zakresie własnej odrębności kulturowej i akceptacja tych różnicujących - na tle innych zbiorowości cech (por. Baran 2013, 26).

Badacze zajmujący się tożsamością (socjologowie, antropolodzy, kulturolodzy, językoznawcy) zgodnie przyjmują, że do podstawowych czynników określających ludzką tożsamość należy język (por. Tambor 2010). Jeśli uznajemy język za „zasadniczy czynnik w byciu człowiekiem”, musimy przyjąć, że język i tożsamość są „ostatecznie nierozerwalne” (Edwards 2009, 20).

Jak zauważa Witold Misiuda-Rewera:

Język jako czynnik kulturotwórczy jest przede wszystkim dobrem wspólnym, które umożliwia jednostkom wzajemną komunikację w odniesieniu do systemów wartości, dzięki którym mamy możliwość realizowania swojej osobowości. To one wyprowadzają nas z alienacji [podkr. E.B.] do czynnego udziału we wspólnocie, w życiu zbiorowym (Misiuda-Rewera 2016, 15).

${ }^{3}$ Magda Karkowska zwraca ponadto uwagę, że na sposoby doświadczania świata przez młodych ludzi mają wpływ także takie konstrukty, jak: światopogląd religijny i polityczny, wybór wykształcenia i zawodu, identyfikacje z kulturą, czas i miejsce rozumiane jako tworzywo tożsamości, społeczne podstawy budowania tożsamości płciowej, a także zachowania buntownicze i dewiacyjne (Karkowska 2013, 157). 
Jako twór społeczny język odsyła nas do pojęcia tożsamości społecznej, zbiorowej, która nie może być

zwykłą ekstrapolacja pojęcia tożsamości jednostkowej, bowiem ,żadna zbiorowość społeczna, do której można byłoby odnieść pojęcie tożsamości, nie ma psychicznego organu samowiedzy produkującego coś, co można byłoby uznać za ścisły odpowiednik samoświadomości osobniczej” (Kłoskowska 1992). Pojęcie tożsamości zbiorowej nieuchronnie prowadzić musi do skoncentrowania uwagi na relacji jednostka-kultura. Tożsamość zbiorowa byłaby w takim ujęciu przyswojeniem przez jednostkę (wpleceniem w jej osobniczą tożsamość) istotnych (walentnych) elementów kultury danej zbiorowości (narodu). Stanowią one podstawę, na której budowana jest „pewna odrębność od obcych i poczucie związku z grupą swoich oraz świadomość ciagłości, historycznego trwania tej grupy i jej zbiorowej filiacji” oraz kształtowane są mechanizmy konstruowania podziałów wyznaczających granice swojskości i obcości - w takim ujęciu fenomen tożsamości narodowej jest zawisły od fenomenu kultury narodowej (Szpociński 2000, 7-15, za: Kornacka-Skwara 2011, 116-117).

Spojrzenie takie odpowiada kulturowemu podejściu do tożsamości narodowej w pracach Antoniny Kłoskowskiej. Badaczka odnosi pojęcie tożsamości narodowej do całej zbiorowości jednostek cechujących się zbieżnością subiektywnych postaw w odniesieniu do własnej grupy kulturowej. Jednostki te podzielaja taka sama „identyfikację narodową”, która definiowana jest jako konglomerat obiektywnych, obserwowalnych z zewnattrz cech zachowania jednostek oraz ich aktów świadomości, ich samoidentyfikacji jako członków określonej wspólnoty kulturowej (Kłoskowska 1992, 7).

\section{Tożsamość a język}

Relacje między językiem a tożsamością wydają się niezwykle złożone, wielopłaszczyznowe i chyba nie do końca możliwe do zgłębienia. Zależności między analizowanymi pojęciami maja ponadto charakter zwrotny: nie tylko język wpływa na naszą tożsamość (co wydaje się dzisiaj oczywistościa), ale i tożsamość wpływa na nasz sposób komunikowania się. Spróbujmy dla porządku wyznaczyć najważniejsze płaszczyzny ich relacji. 
Po pierwsze, język pełni funkcję identyfika cyjną: pomaga określić, kim jestem, zakotwicza w czasoprzestrzeni i kulturze: „Język identyfikuje swojego użytkownika jako członka wspólnoty, narodowej czy etnicznej” (Walczak 2013, 116). Wspólnot tych jest znacznie więcej i mają one bardzo różny zasięg: od międzynarodowych (por. Unia Europejska), przez wspólnoty/kultury narodowe, aż po kultury regionalne, lokalne, po całkiem prywatne mieszczące się w pojęciu małej ojczyzny. W nieco innym wymiarze możemy uwzględnić tutaj informowanie, tj. manifestowanie bądź zdradzanie (por. funkcja prezentatywna języka), o przynależności lub nieprzynależności do pewnych grup społecznych poprzez używanie języka (na przykład socjolek$\left.\mathrm{tu}^{4}\right)$. W najwęższym rozumieniu mówilibyśmy także o idiolekcie jako „,indywidualnym sposobie korzystania z zasobów języka" (Skudrzykowa, Urban 2000, 50). Używanie języka „społecznego” kształtuje tożsamość społeczną jednostki, idiolekt zaś wyraża „indywidualne właściwości, odrębność i wyjątkowość" jednostki analogicznie do tożsamości indywidualnej5.

Po drugie, ,język wielorako i wielopłaszczyznowo integruje społeczność swoich użytkowników" (Walczak 2013, 116; podkr. - E.B.), przy czym nie chodzi o traktowanie języka wyłącznie jako systemu komunikowania, jest on bowiem składnica „elementów pozwalających wyartykułować odrębność kulturową albo nawet cywilizacyjna danego społeczeństwa (...). Innymi słowy język, albo też dokładniej pewna odmiana języka, staje się jednym ze sposobów wyrażania zespołowej, wspólnotowej tożsamości”6 (Lubaś 2009, 97).

${ }^{4}$ Jak dowodzi Wojciech Kajtoch, używanie swoistej leksyki i stylu wypowiedzi wśród subkultur młodzieżowych wzmacnia ich poczucie tożsamości grupowej, idzie o takie zjawiska, jak: 1) nazywanie i wyodrębnianie z ogółu zjawisk elementów wyglądu i trybu życia charakterystycznych dla subkultury oraz prowadzenie dyskursu o ulubionej muzyce, 2) wyodrębnianie swojej grupy i siebie spośród analogicznych grup i zaznaczanie ogólnośrodowiskowej solidarności, 3) zaznaczanie poprzez wybrane sposoby mówienia swojej negatywnej postawy wobec świata, np. dorosłych, 4) zaznaczanie i utrwalanie swoistego światopoglądu poprzez konstruowanie tekstów wartościujących (w sposób zmanipulowany) elementy rzeczywistości i pozorujących związki między nimi (por. Kajtoch 2000, 215-216).

5 Władysław Lubaś mówi „o kilku "piętrach« tożsamości, którą daje się scharakteryzować za pomocą używanego przez daną jednostkę i/lub wspólnotę języka, a którą reprezentują: 1. identyfikacja indywidualna (osobowa), która może być scharakteryzowana przez idiolekt, 2. regionalna (lokalna), tzn. etniczna, narodowościowa, którą można zidentyfikować za pomocą regionalizmów, dialektów wiejskich i miejskich, interdialektów, 3. narodowa, którą zwykle określa się za pomoca jakiegoś języka standardowego, 4. internacjonalna, gdy jakaś grupa społeczna znajduje się w stanie integracji międzynarodowej (np. w Unii Europejskiej) i posługuje się wieloma językami” (Lubaś 2009, 99).

${ }^{6} \mathrm{Jacek}$ Warchala i Aldona Skudrzyk zwracają uwagę na rolę języka potocznego, który integruje małe społeczności, ale też pełni funkcję ekspansywnego interdialektu: „Widzenie świata 
Renata Grzegorczykowa mówi w podobnym kontekście o roli języka pełnionej przez całość działań językowych danej społeczności, narodu (Saussurre'owskie langage ${ }^{7}$ ) zaobserwowaną ex post. Funkcja socjalizująca języka polega właśnie na jednoczeniu członków zbiorowości (Grzegorczykowa 2007, 55). Integrującą funkcję mogą mieć też prestiż ${ }^{8}$, jaki daje wspólny język będący świadectwem wyższej organizacji społecznej oraz rama odniesienia normatywnego, tj. istnienie zasad co do używania języka (por. Bokszański, Piotrowski, Ziółkowski 1977, 67-68).

Po trzecie, pozwala określić, kim nie jestem: odróżnić się od innych (funkcja dyferencjacyjn a lub separująca, por. Bokszański, Piotrowski, Ziółkowski 1977, 67-68): „wreszcie język, integrując wewnętrznie wspólnotę, jednocześnie automatycznie odróżnia ją od innych wspólnot, posługujących się innymi językami...” (por. Walczak 2013, 116). Język jawi się tutaj jako artefakt konstytuujący kulturową odrębność:

Zawsze na jakość roli języka jako składnika tożsamości kulturowej wpływ maja procesy rozwoju społecznego, politycznego, kulturowego. Język pozwala społeczności zrozumieć siebie jako jedność, ponieważ przez długie trwanie wytwarza znamiennie dla danej społeczności sposoby określania i nazywania świata i różne odcienie jego konceptualizacji (Skudrzyk, Urban 2010, 59-60).

Warto zwrócić tutaj uwagę na rolę stereotypów narodowościowych, które pozwalają ocenić inne postawy niż te, które uważa się za swoje (Bartmiński, Panasiuk 1993, 363-387).

i problemów z perspektywy JA (+ TY) wprowadza do naszego myślenia o jezzyku potocznym perspektywę utrwalania tożsamości w ramach małej grupy społecznej: rodzinnej i sąsiedzkiej; genetycznie język potoczny jest językiem wspólnotowym ze sfery prywatnej, przeciwstawiajacym się sferze publicznej; jest to język rodziny, język, w którym się odnajdujemy jako członkowie grupy lokalnej, ale też język ponadlokalny, interdialektalny. Lokalność i regionalność utrwala opozycja: język wernakularny (gwary i języki lokalne) vs. język potoczny dolnego rejestru. Przeciwstawienie sfery lokalnej i regionalnej sferze publicznej pokazuje rolę języka mówionego-potocznego i wernakularnego w utrzymaniu tożsamości na poziomie Gemeinschaft (heterogenicznie pojmowanej wspólnoty), i języka ogólnego na poziomie Gesellschaft (społeczeństwa, stowarzyszenia)" (Warchala, Skudrzyk 2010, 80-81).

$7 \mathrm{~W}$ takim rozumieniu o języku mówi się w zdaniach typu: Jesylk polski w cžasach zaborów byt caynnikiem jednoczacym Polakón, Jesykejest środkiem komunikagï spotecznej (Grzegorczykowa 2007, 53).

${ }^{8}$ Historia języka to świadectwo rozwoju kultury, a jedna z funkcji społecznych jezzyka wspólnoty komunikatywnej jest nadawanie prestiżu tym, którzy się nim posługuja (Bańkowska, Mikołajczuk, red. 2000, 60-61). 
Po czwarte wreszcie, jako zapis pamięci zbiorowej język przechowuje i przekazuje obraz świata kultury czy społeczności ${ }^{9}$. Renata Grzegorczykowa mówi z jednej strony o poznawczej funkcji samego systemu językowego (Grzegorczykowa 2007, 54), uznaje język za klasyfikator świata, który utrwala doświadczenie poznawcze i tym samym w istotny sposób wpływa na kulturę społeczności mówiącej danym językiem, kształtując językowy obraz świata ${ }^{10}$ (Grzegorczykowa 2007, 54). Z drugiej strony Grzegorczykowa mówi o funkcji kulturotwórczej11 (kumulatywnej) pełnionej przez całość tekstów zapisanych lub utrwalonych w pamięci zbiorowej. Funkcja ta polega na ,gromadzeniu i przechowywaniu wiedzy, doświadczenia pokoleń, świata wartości, przechowywaniu w tekstach utrwalonych lub zachowanych w pamięci mówiących" (Grzegorczykowa 2007, 55)12. Wydaje się, że język ma wymienione właściwości nie tylko na poziomie langue i langage, ale też na płaszczyźnie wypowiedzi - parole. Mówimy przecież również o obrazach świata utrwalonych w konkretnych tekstach-wypowiedziach ${ }^{13}$, które tworzą tekstowe obra-

${ }^{9}$ Wpisują się tutaj badania Jerzego Bartmińskiego i przedstawicieli Lubelskiej Szkoły Etnograficznej (termin Jörga Zinkena 2015), którzy w społecznie utrwalonym językowo-kulturowym obrazie świata dokonuja podmiotowej rekonstrukcji tradycji człowieka.

10 Takiej systemowej funkcji języka, jak się wydaje, dotyczą słowa Hansa-Georga Gadamera: „Język (...) nie jest narzędziem. Narzędzie jest bowiem - z istoty - czymś, czego użycie można opanować: narzędzie możemy wziąć do ręki i odłożyć, gdy już spełniło swoje zadanie. Wydawałoby się, że podobnie jest z językiem: bierzemy w usta leżące w pogotowiu słowa jakiegoś języka i pozwalamy, by po użyciu zniknęły z powrotem w ogólnym zbiorze słów, którym rozporządzamy. Ale to nie to samo. Analogia jest fałszywa, ponieważ świadomość nigdy nie stoi naprzeciw świata, sięgając - w stanie bezjęzykowym - po narzędzie porozumienia. We wszelkiej naszej wiedzy o nas samych i o świecie jesteśmy już raczej ogarnięci przez język (...). Językowa wykładnia świata poprzedza zawsze wszelką myśl i wszelkie poznanie. Ucząc się jej, wychowujemy się w świecie zarazem. Dlatego to właśnie język jest właściwym śladem naszej skończoności” (Gadamer 1976, 13).

11 Warto tutaj pamiętać o roli, jaką pełnią uznane teksty artystyczne, tzw. kanon literatury, w kształtowaniu poczucia tożsamości narodowej.

12 Grzegorczykowa mówi dalej o socjalizującej i kulturotwórczej funkcji języka: „Obie funkcje pozostają w ścisłym związku z faktem, że w jednej społeczności odbija się jej sposób myślenia i przeżywania świata (...). Ta właściwość języka powoduje, że wśród członków danej wspólnoty językowej wytwarza się głębsza więź, odwołująca się do wspólnych doświadczeń historycznych i kulturowych”. Dla osób mówiących tym samym językiem „poszczególne słowa mają sens nie tylko racjonalno-denotacyjny, ale są nośnikami złożonych pojęć i treści aksjologiczno-emocjonalnych, nieprzekładalnych na inny język” (Grzegorczykowa 2007, 560).

${ }^{13} \mathrm{Na}$ wielopłaszczyznowość funkcji języka zwraca uwage Jerzy Bartmiński, por.: „Język jest in terpretantem kultury, tak jak jest interpretantem świata, to znaczy za jego pomocą 
zy świata albo, uwzględniając perspektywę ideologiczna, o różnych dyskursach, różnych głosach pokazujących odmienne punkty widzenia i perspektywę oglądu rzeczywistości aktualizujących się w tekstach. Na poziomie dyskursu najpełniej realizowałaby się zasada zwrotności: bowiem to moje poczucie tożsamości wpływa na to, jakich nominalizacyjnych wyborów dokonuję, jak opisuję, wartościuję, argumentuję, o czym mówię, o czym milczę itd.

\section{Badanie świadomości studentów w zakresie wpływu języka na tożsamość}

Interesujące wydaje się sprawdzenie, w jaki sposób relacje między językiem a tożsamościa postrzegają ludzie młodzi, u progu dorosłości; które z powyższych związków języka i tożsamości dostrzegaja. Aby przybliżyć to zagadnienie przeprowadzono badania ankietowe wśród 66 studentów studiów humanistycznych. Kwestionariusz ankiety rozsyłany był do studentów droga elektroniczną ${ }^{14}$, badania miały charakter anonimowy. W grupie respondentów znalazło się 50 kobiet (76\%) i 16 mężczyzn (24\%), byli to studenci pierwszych lat licencjackich studiów humanistycznych, głównie kierunków:

można wyjaśnić i zinterpretować wszystkie systemy znakowe funkcjonujące w społeczeństwie, także takie, które operują znakami graficznymi, obrazem, dźwiękami, odwołują się do zachowań, postaw i wierzeń. Język może też interpretować siebie (...). Język wreszcie pozostaje w koniecznym związku z systemem wartości, rdzeniem każdej kultury. Nie tylko utrwala i przekazuje wiedzę o wartościach, co mieści się w ramach funkcji poznawczej, ale też służy jako narzędzie wartościowania (»język wartości« w sformułowaniu Jadwigi Puzyniny) i jest materią, na której realizuja się wartości, takie jak prawdziwość, konkretność, obrazowość, harmonia itp. Jako dobro wspólne, podstawa tożsamości wspólnoty, przewodnik po świecie, czynnik więzi międzyludzkiej - język jest w kulturze także wartością autonomiczną” (Bartmiński 2014, 20-21). Ponadto: „W języku są zmagazynowane także wytwory działań kulturowo-językowych: formuły etykiety grzecznościowej (dobrodzieju, towarzyszu, pani), wzorce wypowiedzi stosownych do okoliczności i odpowiednich do intencji nadawcy (toast, skarga, podanie itp.), całe klisze tekstowe (praysłowia, sentencje, modlitwy, pieśni, bajki itp.), wreszcie także style językowe, których wielość jest efektem historycznej dyferencjacji kultury. Dzięki temu język, zwłaszcza jego słownictwo i teksty, funkcjonuje także jako archiwum kultury, jej pamięć utrwalająca to, co było. Wszystko to pozwala mówić o poznawczej funkcji języka w stosunku do kultury. Skumulowanie w języku wytworów przeszłości umożliwia ludziom porozumiewanie się poprzez granice wieków i krajów” (Bartmiński 2014, 20).

14 Przez grupowe skrzynki pocztowe oraz portale społecznościowe. Dobór próby można więc uznać za częściowo losowy. 
komunikacja promocyjna i kryzysowa, filologia polska i sztuka pisania. Należałoby się u tych studentów spodziewać refleksyjnego podejścia do języka, który stanowi ważny (jeśli nie najważniejszy) przedmiot poznania w programach tych kierunków. W chwili badania 63\% badanych miało 21 lat lub mniej. Przedmiot niniejszych badań stanowiła świadomość młodych ludzi na temat wpływu języka na kształtowanie się (ich) tożsamości. Pytania dotyczyły m.in. postrzegania języka ojczystego, w tym też stosunku do poprawności językowej, zapożyczeń i gwary, rozumienia tożsamości, relacji między językiem (w tym gwara) a tożsamością. Ankieta składała się z 19 pytań ${ }^{15}$, w tym miejscu przedstawię jedynie wnioski płynące $z$ analizy pierwszych siedmiu pytań.

Przeprowadzone skromne badania mają formę rekonesansu, rozeznania ocen studentów dotyczących roli języka w kształtowaniu poczucia tożsamości. Pytania zadane studentom miały charakter ogólny, aby nie naprowadzać ich na konkretne odpowiedzi i aby dać im możliwość pełnego wypowiedzenia się na badany temat; charakter pytań miał w założeniu przydać badaniom waloru jakościowego, co też częściowo rekompensuje ich niepełny zasięg. Celem badań jakościowych powinna być „pogłębiona wiedza na jakiś

15 Oto wszystkie pytania, które pojawiły się ankiecie: 1. Czym jest dla Ciebie język polski/język ojczysty? 2. Jak rozumiesz słowa Ludwiga Wittgensteina: „Granice mojego języka są granicami mojego świata”? Zgadzasz się z nimi? Odpowiedź uzasadnij. 3. Jak rozumiesz pojęcie tożsamość? 4. Czy dostrzegasz relację między językiem a tożsamością? 5. Jeżeli odpowiedziałeś twierdząco na poprzednie pytanie, opisz, w jaki sposób postrzegasz relację między językiem a tożsamością. 6. Które zdanie najlepiej oddaje Twój stosunek wobec języka: (...) 7. Jak jeszcze opisałbyś Twój stosunek do języka polskiego/ojczystego? 8. Jak opisałbyś Twój stosunek do poprawności językowej? 9. Jak opisałbyś Twój stosunek do obecności w języku polskim/ojczystym zapożyczeń? 10. Czy znasz jakieś słowa/wyrażenia języka polskiego/ojczystego, które trudno przetłumaczyć na inne języki bez zmiany ich znaczenia? Podaj przykłady. 11. Czy odmiany języka, jakimi się posługujesz, wyrażają Twoja przynależność do różnych grup społecznych? Odpowiedź uzasadnij. 12. Czy język, którego używasz, pozwala Ci się wyróżnić na tle innych? Odpowiedź uzasadnij. 13. Czy język, którego używasz, wpływa na Twoją integrację i poczucie więzi z otoczeniem? Odpowiedź uzasadnij. 14. Jak rozumiesz pojęcie: bariera językowa? 15. Czy jesteś w stanie zaprzyjaźnić się/wejść w związek intymny z osobą, która posługuje się innym językiem niż Twój język ojczysty? 16. Czy w Twoim domu rodzinnym posługiwano się gwarą? 17. Jak opisałbyś Twój stosunek do gwary? 18. Jak myślisz, w jaki sposób gwara może kształtować tożsamość? 19. Czy znasz jakieś słowa lub wyrażenia, które są obecne w gwarze śląskiej/innej, a których nie sposób oddać za pomoca języka polskiego/narodowego? Podaj przykłady. Metryczka obejmowała jedynie płeć respondentów, wiek i kierunek studiów. 
temat, dotarcie do sedna problemu, jak najpełniejsze poznanie istoty zjawiska"16 (Krok 2015, 57). Wykorzystane w kwestionariuszu otwarte i półotwarte pytania miały za zadanie dotarcie do głęboko ukrytych przekonań i emocji, stąd też konieczne wydaje się odwołanie do cytatów (por. Babbie 2004; Krok 2015, 57).

Inspiracją do podjęcia tego tematu stały się wcześniejsze badania ankietowe, które przeprowadziłam w lutym 2017 r. na grupie 122 studentów studiów humanistycznych, a których celem było dookreślenie tożsamości młodych ludzi w kontekście zmian cywilizacyjnych. Wiek badanych (18-22 1.) to okres kształtowania się dojrzałej hierarchii wartości i koncepcji własnego Ja (okres tzw. późnej adolescencji według Erika Eriksona). Badania wykazały, że na poczucie tożsamości studentów największy wpływ ma ich płeć i narodowość (jedna z dwu najważniejszych identyfikacji dla polowy respondentów). Respondenci podkreślali też znaczenie kultury i wychowania. Wskazywali, że cechuje ich tradycyjna hierarchia wartości, duże znaczenie przypisują rodzinie, miłości i przyjaźni. Z drugiej strony połowa ankietowanych uznała, że nie ma żadnych autorytetów. Studenci dostrzegają oddziaływanie Internetu na kształtowanie tożsamości, przy czym wpływ ten oceniają raczej wyłącznie pozytywnie (w kategoriach szansy: jako nieograniczone możliwości wyboru tego, kim będę). Zaskoczeniem w przeprowadzonej analizie okazał się fakt, iż studenci nie czuja się katolikami (nieraz wręcz manifestacyjnie się od tej kategorii odcinaja) (zob. Kałuzińska 2017).

Bezpośrednia przyczyna podjęcia tematu stały się odpowiedzi studentów na zadane im wówczas pytanie: „Które czynniki uznałbyś za ważne elementy Twojej tożsamości? Możesz zaznaczyć dowolną liczbę odpowiedzi”. Okazało się tutaj, że jedynie nieco ponad połowa badanych uznaje język ojczysty za ważny element tożsamości. Aby zinterpretować otrzymany wynik, można odwołać się do badań ankietowych Kazimierza Przyszczypkowskiego (1998), który ustalił, że ,język sytuuje się bardzo wysoko na skali wyznaczników tożsamości (identyfikacji) narodowej”. Na język polski jako ważny wyznacznik tożsamości narodowej wskazało w jego badaniach 89\% respondentów. Badania Przyszczypkowskiego pokazały, że ,język polski jest nie tylko najważniejszym kulturowym wyznacznikiem polskości, lecz w ogóle pierwszym i najpoważniejszym jej determinantem...” (za: Walczak 2013,

${ }^{16}$ Nadają się do opisu cech, procesów, które nie są kwantyfikowalne (o ile w ogóle są mierzalne) w kategoriach ilości lub wielkości (Denzin, Lincoln 2009). 
121-122) ${ }^{17}$. Skoro zatem w moich badaniach studentów identyfikacja narodowa okazała się jedną z dwu najistotniejszych, należałoby oczekiwać wyniku znacznie wyższego. Na uwagę zasługuje też fakt, że większość respondentów stanowili studenci filologii polskiej, dla których język powinien być wartością autoteliczną. Można przypuszczać, że w innej grupie badawczej wynik ten byłby niższy.

Z przeprowadzonych badań wynikało ponadto, że młodzi Ślązacy nie identyfikują się ze swoją przynależnością etniczną, co potwierdziły także odpowiedzi na pytania dotyczące gwary - które pokazały jej marginalne znaczenie (por. Kałuzińska 2017). Okazało się, że gwara nie stanowi języka porozumienia dla respondentów pochodzących ze Śląska, a przecież odrębność językową często wskazuje się jako jeden z najistotniejszych czynników więzi w ramach grupy etnicznej (Tambor 2010).

Wydaje się zatem, że młodzi dorośli nie doceniają roli języka w kształtowaniu tożsamości, a przecież „jak twierdzi Taylor, język jako twór społeczny »wprowadza do tego procesu zarówno wspólnotę ludzką, jak i udział konkretnych osób, które odegrały w życiu jednostki istotną rolę«" (Rosner 2006, 36). Aby przekonać się, czy intuicje wynikające z poprzednich badań są słuszne, postanowiłam przeprowadzić kolejną ankietę w tej samej grupie wiekowej18.

Badając świadomość roli języka w procesie kształtowania to żsamości, warto odwołać się do pojęcia świadomości językowej, pojmowanej jednak nie tylko jako wiedza o języku, o poprawności językowej, ale w ujęciu szerszym, zaproponowanym przez Wojciecha Chlebdę, a mianowicie jako:

zdolność człowieka do zdawania sobie sprawy ze stanu rzeczywistości językowej, w jakiej jest zanurzony, proces jej ujmowania (postrzegania, kategoryzowania, przetwarzania, internalizacji), wreszcie rezultat tego procesu w postaci pewnego złożonego, tematycznie określonego konstruktu mentalnego (Chlebda 1995, 24).

17 Wyniki te pozostają w zgodzie z opiniami innych badaczy, por.: „niektórzy badacze postrzegają wręcz język narodowy jako siłę sprawczą, demiurga tożsamości narodowej. Joshua Fishman, autor licznych prac z dziedziny socjolingwistyki, opisuje związek między tożsamością narodową a językiem w sposób następujący: »Kwintesencję narodowości stanowi jej duch, jej osobowość, jej istota. Istota ta nie tylko zostaje odzwierciedlona i zachowana w języku ojczystym, ale w pewnym sensie to język ojczysty sam staje się aspektem owej istoty, jej częścia, a nawet wręcz jej manifestacją" (Fishman 1973, 153, za: Kuczkiewicz-Fraś 2012, 124).

18 Badania zostały przeprowadzone w październiku $2017 \mathrm{r}$. 
Autor szczegółowo opisuje czynniki wchodzące w skład tak rozumianej samoświadomości językowej ${ }^{19}$, wśród których znajdują się m.in. myślenie o przynależności do zbiorowisk ludzi mówiących podobnie i nieprzynależności do innych, a także poczucie więzi i bliskości ze wspólnotą językowa. Tak pojmowana świadomość językowa staje się warunkiem świadomości roli języka w kształtowaniu tożsamości.

Pytanie pierwsze miało charakter rozpoznawczy, wprowadzający i brzmiało: „Czym jest dla Ciebie język polski/język ojczysty?”. Odpowiedzi studentów można podzielić na takie, w których studenci uznają język przede wszystkim za środek komunikacji (28\%), oraz takie, które widzą w nim coś jeszcze $(60 \%)$. Dla ponad połowy badanych język polski/ojczysty jest czymś więcej niż środkiem komunikacji, por.:

- Przede wszystkim jest wartością, czymś, z czym się utożsamiam i staram się pielęgnować;

- Język ojczysty jest dla mnie istotnym symbolem przynależności narodowej, sposób kreowania wypowiedzi w języku ojczystym przez ludzi potrafi wiele powiedzieć o danej osobie;

19 „Odpowiedzmy opisowo, że będzie to, chyba przede wszystkim, myśl o tym, że mówię - i że poprzez tę zdolność przynależę do określonych (mówiących podobnie) zbiorowisk ludzi (a nie przynależę do zbiorowisk innych, mówiących inaczej). (...) Dołączyć się tu może poczucie więzi i bliskości wobec tych, których treść i sam sposób mówienia nie odbiega od mojego - i np. poczucie obcości czy niechęci wobec wypowiadających się odmiennie. Do ważnych składników odniosę przekonanie, że moje mówienie wywiera wpływ na innych ludzi - dokładnie tak, jak mówienie innych wywiera wpływ na mnie; mam przeświadczeni e, że mogę ten wpływ regulować i do jakichś granic nim sterować (i że inni są w stanie podobną „regulację” zastosować wobec mnie). Mam też przekazaną mi wiedzę, że tak jak w pewnych okolicznościach jedne formy językowe są wręcz zalecane i skutkują korzystnie, tak w innych okolicznościach użycie tych form jest niewskazane (bo niekorzystne) bądź zakazane; wiedzę tę wspieram intuicją, a gdy użycie intuicyjne zweryfikuję w praktycznym dialogu z ludźmi, efekt tej weryfikacji włączam do swojej wiedzy prywatnej (...), doznaję zadowolenia, gdy to, co mówię, wyraża dokładnie to, co chciałem powiedzieć - i dyskomfortu, gdy dla swej myśli nie mogę dobrać odpowiednich słów; św ia do mość tego dyskomfortu popycha mnie ku poszukiwaniom rozwiązań bardziej adekwatnych, które memu odbiorcy (rozmówcy, czytelnikowi) ukażą me myśli, intencje i motywacje jaśniej. Mam ro z e zn anie, że dysponuję pewnym zapasem środków językowych dla takich poszukiwań, powoduje też mną ch hęć, by w razie poczucia niewystarczalności tego zapasu wzbogacić jego zasoby. (...). Myślę, że jej [samoświadomości językowej - E.B.] podstawę stanowi stale gromadzona i świadomie porządkowana wie dza (w szerokim sensie tego słowa), zdolność dokonywania (s a mo) oceny oraz zespół czynników wolicjonalnych - chęci, potrzeby, postanowienia odnośnie do podejmowania takich, a nie innych decyzji i działań językowych (Chlebda 1995, 24-45; por też: Skudrzyk, Urban 2010, 20-21). 
- Jest środkiem komunikacji, ale także sposobem wyrażania myśli i uczuć;

- Jest jednym z najważniejszych elementów określających to, kim jestem. Ponadto jest również czymś, co mnie interesuje. Jest wartością niematerialną i elementem mojej tożsamości narodowej;

- Narzędziem identyfikacji mojej tożsamości, świadectwem mojego pochodzenia;

- Integralną częścią mojego życia i tożsamości.

Zwróćmy uwagę, że już w odpowiedziach na to pytanie pojawia się pojęcie tożsamości, które wprawdzie jest zawarte w tytule ankiety, pytanie natomiast bezpośrednio się do niego nie odnosi.

Pytanie drugie dotyczyło rozumienia słów Ludwiga Wittgensteina: „Granice mojego języka są granicami mojego świata”. Studenci w zdecydowanej większości (85\%) zgadzają się ze słowami filozofa, przy czym rozumienie tych słów bywa rozmaite. Pojawiają się odpowiedzi świadczące o znajomości cytatu, a nawet o znajomości odpowiedniego kontekstu teoretycznego, por.:

Jeśli czegoś nie potrafię nazwać, to nie mogę o tym myśleć, a więc jest to w pewnym sensie poza obrębem świata, który dostrzegam. Cytat ten dobrze koresponduje z innym powiedzeniem: „Język drąży ścieżki myślom”. Im bogatszy jest mój język, tym szersze jest moje myślenie. Zdecydowanie zgadzam się z tymi słowami, ponieważ język kształtuje nasz sposób postrzegania świata. Jak wiadomo, ludzie myślący w różnych językach nieco inaczej doświadczają pewnych elementów świata (przykład z wieloma określeniami ‘śniegu' u Eskimosów albo brak rozróżnienia pojęć 'siostra-brat' u pewnego plemienia Indian). Mówi o tym zresztą również prawo relatywizmu językowego Sapira-Whorfa;

Wydaje mi się, że autorowi chodziło o to, że człowiek dzięki znajomości języka, potrafi nazwać to, co jest w stanie poznać dzięki językowi. Wszystko, co widzi, co zna, co jest w stanie nazwać, nazwie, bo ma taka wiedzę. Jeśli spotka coś nowego, coś, co pochodzi na przykład z innej kultury, co jest mu zupełnie nieznane, może mieć trudność z określeniem tej rzeczy, ponieważ nigdy wcześniej nie miał z nią styczności. Tak, zgadzam się, ponieważ niejednokrotnie doświadczamy takiego zjawiska w swoim życiu;

Tak. Językowy obraz świata jest realny. Każdy kształtuje nim swoje wyobrażenia. 
Najczęściej jednak studenci rozumieją słowa Wittgensteina pragmatycznie, w odniesieniu do znanych im z doświadczenia problemów komunikacyjnych i praktyk językowych. Prawie 30\% badanych (20 osób) rozumie przytoczone słowa w odniesieniu do języków obcych, mianowicie: znajomość języków obcych umożliwia poznawanie innych kultur, a to poszerza nasze horyzonty:

Zgadzam się z mottem, uważam, że znajomość różnych języków i ich odmian umożliwia komunikację na całym świecie. Znajomość wielu języków sprawia, że granice międzyludzkie i te między państwami zacierają się. Dodatkowo poszerzanie granic języka to poszerzanie wiedzy i umiejętności...;

Rozumiem to przede wszystkim w kontekście języków obcych (może dlatego, że ten napis wisiał na drzwiach sali z angielskiego w mojej szkole :)) mogę poznawać świat i inne kultury, jeśli będę w stanie się porozumieć z ludźmi, którzy do nich należą. Ale rozumiem te słowa także w obrębie tylko jednego języka - im więcej znam słów, stylów językowych, tym bardziej moge „dopasować się” do różnych sytuacji, lepiej je zrozumieć;

Zgadzam się, gdyż poprzez naukę innych języków można dogadywać się z większą ilością ludzi, a także dowiadywać się o ich świecie i kulturze.

Niektórzy uznają, że w dobie globalizacji słowa te tracą na znaczeniu, przestają być aktualne, por.:

W dzisiejszym świecie, kiedy świat jest otwarty i różne kultury oraz języki przenikają się ze sobą, te słowa wydają się bardzo przestarzałe. Być może my, Polacy, możemy się w nich jeszcze odnaleźć, ponieważ nasz język jest trudny dla obcokrajowców i nie obowiązuje w żadnym innym państwie, natomiast mieszkańcy krajów, gdzie językiem urzędowym jest język angielski bądź francuski, dogadaja się niemal wszędzie. Znajomość języków przesuwa granice;

60 lat temu filozof miał rację, ale w naszym czasie, epoce internetu i komunikacji języki obce pozwalają nam poszerzyć swoją świadomość jakby o drugiego człowieka, zyskując jednocześnie klucz do jego kultury.

W sumie jedynie 10 osób (15\%) nie zgadza się z tymi słowami, uznając, że są inne sposoby porozumiewania niż język (np. sztuka) oraz że języków można się nauczyć, więc ich aktualna znajomość nie ma charakteru determinującego. Tutaj też widać niestandardowe odczytanie intencji cytatu. 
Pytanie kolejne dotyczyło bezpośrednio pojęcia tożsamości: „Jak rozumiesz pojęcie tożsamość?". Studenci na ogół nie maja problemu z określeniem, czym jest tożsamość, 40\% respondentów podaje szeroką i ogólną definicję tożsamości, np. „Coś, co mnie określa, to, kim jestem”, „Coś, co jest ze mną spójne, z czym się identyfikuje". Pozostałe odpowiedzi równomiernie rozkładają się na charakterystykę tożsamości indywidualnej (por. „Jest to pewna indywidualność, która rozróżnia nas od innych”; „kojarzy mi się z osobowością, indywidualnością, czymś niepowtarzalnym”) i społecznej (por. „Tożsamość to poczucie przynależności do danego miejsca, grupy itp.”; „Przynależność do grupy, z której kultura/ideami zgadzamy się i czujemy się związani”) - po $25 \%$.

Pytanie czwarte miało charakter zamknięty: „Czy dostrzegasz relację między językiem a tożsamością?”. 80\% studentów odpowiedziało na to pytanie twierdząco, 16\% uznało, że nie ma zdania w tej kwestii. Pytanie piąte odnosiło się tylko do tych respondentów, którzy dostrzegają relację między językiem a tożsamością: „Jeżeli odpowiedziałeś twierdząco na poprzednie pytanie, opisz, w jaki sposób postrzegasz relację między językiem a tożsamością". Prawie połowa respondentów (45\%), którzy udzielili odpowiedzi na to pytanie, dostrzega relację między językiem a tożsamością społeczną, w tym zwłaszcza narodowa; język pozwala utożsamiać się z polską historią i kulturą jest też ważnym elementem wpływającym na autodefinicję (Ślązak):

Język może być narzędziem/wspólnym elementem dla grupy, z którą się utożsamiamy. Na przykład, język polski jest cechą wspólną dla Polaków, z którymi możemy się utożsamiać;

Język wpisuje się w to, kim jestem, więc jest częścią mojej tożsamości. Gdy wracam z zagranicy, wielką ulgę sprawia mi słuchanie własnego języka, dzięki któremu czuję się bezpiecznie;

Przez język czuję się Polakiem, Ślązakiem (czasami wdrażam śląskie wyrazy do zdania);

Często to język, którym się posługujemy, determinuje to, jak się określamy. Najlepszym przykładem sa gwary. Osoba władająca gwara śląską określi się jako Ślązak.

Nieco ponad jedna czwarta badanych (26\%) uznaje, że język pomaga wyrazić siebie. Studenci zwracaja przede wszystkim uwagę na prezentatywną funkcję języka: 
Język jest ściśle związany z osobowością człowieka. Jeśli człowiek jest niewykształcony, nie będzie sięgał po wygórowane słownictwo, a użyje prostych środków. Zupełnie inaczej postąpi człowiek wykształcony, który zanim wypowie się, pomyśli nad formą i przesłaniem;

Język każdego z nas, jak go używamy, jaki mamy zakres słownictwa, dużo mówi o nas samych i przekazuje wiedzę o naszej tożsamości...;

Człowiek wyraża siebie za pomocą języka, język to element kultury, z którą człowiek jest silnie związany;

Po sposobie zachowania, upodobań można wywnioskować, w jaki sposób będzie ktoś mówił i odwrotnie. Przykładowo osoba dostojna, elegancka nie będzie mówić w sposób totalnie kolokwialny.

Co piąty badany uważa, że język jest formą myślenia i poznawania rzeczywistości - a te z kolei wpływają na naszą tożsamość:

Język kształtuje nasze postrzeganie świata i sposób, w jaki myślimy o świecie, ale także o nas samych...;

Język wiąże się z naszym postrzeganiem świata, ponieważ za jego pomocą go opisujemy, a nasze postrzeganie świata wpływa na naszą tożsamość.

Studenci (w odpowiedzi na pytanie 6.) mieli też wybrać zdanie, które najlepiej oddaje ich stosunek wobec języka. Możliwości były następujące: ,język jest dla mnie przede wszystkim środkiem komunikacji, jego wartość polega na użyteczności”; ,język jest dla mnie wartością samą w sobie”; „język nie jest dla mnie wartością”, „inna odpowiedź, jaka?”. Respondenci dzielą się tutaj równomiernie, na tych, dla których język jest przede wszystkim środkiem komunikacji (45\%), i na tych, dla których jest wartością autoteliczną $(42 \%)$. Inne odpowiedzi niemalże bez wyjątku opisują stanowisko pośrednie: język jest jednym i drugim. Tylko jedna osoba uznała, że język nie jest dla niej wartościa. Odpowiedzi na to pytanie nie pokrywają się z odpowiedziami na pytanie pierwsze - gdzie studenci sami podkreślali, że język jest czymś więcej niż środkiem komunikowania. Być może uznanie języka za wartość wydaje się części studentom patetyczną przesadą. 
Ponad 90\% respondentów deklaruje pozytywny stosunek do języka polskiego. W odpowiedzi na pytanie siódme: „Jak jeszcze opisałbyś swój stosunek do języka polskiego/ojczystego?” studenci podkreślali, że język polski jest trudnym (7), ale pięknym językiem (7), o który należy dbać (6). Szanują go (5), lubią (5), są z niego dumni (5):

Jest czymś, o co należy dbać i pielęgnować, jednocześnie nie zamykając mu drogi do rozwijania się przez nadmierny puryzm. Żałuję, że tak mało osób ma świadomość, jak poprawnie używać języka polskiego;

Jestem dumna, że mówię po polsku;

Jest ważnym elementem życia, o który trzeba dbać i świadomie przekazywać następnym pokoleniom;

Staram się go szanować, choćby ze względu na to, że jest to jeden z najtrudniejszych języków na świecie;

Jest to jeden z najtrudniejszych języków, który wyraża najwięcej emocji;

Jest dla mnie ważny i jestem dumna $z$ tego, że znam język polski i że jest to mój język ojczysty, gdyż jest jednym z najtrudniejszych na świecie.

Pozostali uznali swój stosunek wobec języka ojczystego za obojętny.

\section{Zakończenie}

Przeprowadzone skromne badania i niepełna analiza zebranego materiału nie pozwalają na ostateczne rozstrzygnięcia. Z pewnościa powiększenie grupy respondentów, a także skrupulatna analiza ilościowa mogłyby rzucić dodatkowe światło na badane zagadnienie. Stosunkowo duża jednomyślność respondentów sprawia, że możliwe wydaje się jednak zarysowanie wstępnych wniosków. Przede wszystkim większość studentów uznaje, że język ojczysty jest dla nich czymś więcej niż środkiem porozumiewania się, a dla prawie połowy badanych stanowi wartość autoteliczną. Z wypowiedzi studentów wyłania się niezwykle pozytywny obraz samej polszczyzny jako trudnego, ale i pięknego języka, dobra narodowego, o które trzeba dbać. Należy przy tym zauważyć, że badana grupa to studenci studiów humanistycz- 
nych, z których większość spotyka się w czasie studiów z instruktażem ze strony kadry akademickiej na temat pożądanego stosunku wobec języka, przy czym przejmowanie tych poglądów należy uznać za zjawisko pozytywne. Warto także pamiętać, że opisany stosunek wobec języka, podobnie jak inne odpowiedzi studentów mają charakter deklaratywny, nie wiemy, na ile są to ich rzeczywiste postawy.

Ciekawe wydaje się rozumienie słów Wittgensteina: „Granice mojego języka są granicami mojego świata”. Odpowiedzi studentów, choć często niezgodne $z$ intencją filozofa, pokazują ich pragmatyzm, nastawienie na konkret i bezpośrednie doświadczenie, a także gotowość do zmian, np. możliwość nauki nowych języków.

Respondenci dobrze rozumieja pojęcie tożsamości, uznając, że tożsamość określa to, kim są. Rozkład między pojmowaniem tożsamości w kategoriach społecznych i jednostkowych okazał się równomierny. Pozytywnie należy ocenić fakt, że zdecydowana większość (80\%) studentów dostrzega relację między językiem a tożsamością. Relację ową studenci postrzegają w kilku wymiarach. Najczęściej wskazuja związek języka z kulturą narodową i etniczną. Język identyfikuje ich jako członków zbiorowości, daje poczucie przynależności do wspólnoty, a nawet poczucie bezpieczeństwa. Pozwala ponadto wyrazić własną niepowtarzalność, ale też zdradza nasze pochodzenie czy wykształcenie. Studenci wykazali się tutaj świadomością prezentatywnej czy socjolingwistycznej funkcji języka. Część badanych dostrzegła także, że język jest formą myślenia i pośrednicząc w poznaniu świata, kształtuje tożsamość.

Porównanie zaprezentowanych wniosków z poprzednimi badaniami, które nie wykazały podobnej roli języka w kształtowaniu tożsamości studentów, prowadzić może do konkluzji, że samo sformułowanie pytań pobudziło refleksję młodych ludzi na temat sprawczej roli języka w kreowaniu tożsamości.

Badanie relacji między językiem a tożsamością wydaje się zagadnieniem bardzo atrakcyjnym szczególnie dzisiaj, w dobie globalizacji. Niewyobrażalnie duża ruchliwość społeczna, ekspansja języka angielskiego jako uniwersalnego kodu międzykulturowego czy możliwość kontaktu z osobami z całego świata wywołują dwie przeciwstawne tendencje. Z jednej strony

dziś w procesie kulturalizacji ważna staje się kultura symboliczna ponadnarodowa, globalna, zacieraja się granice poszczególnych kultur symbolicznych. Mówić nawet można o symbolicznej dezorientacji, symbolicznym zagubieniu, innymi słowy o sytuacji „globalnego prania mózgu 
i stworzenia cywilizacji ludzi pozbawionych świadomości własnej, jednostkowej odrębności” (Skudrzyk, Urban 2010, 62).

W ten sposób powstaje podatna na wpływy i niestabilna osobowość typu borderline. „Globalna konkurencja zachęca do przenoszenia się i podejmowania nowych wyzwań (...), ale ludzie potrzebuja nie tylko skrzydeł, ale i korzeni" (Dionne 2001, 171), dlatego też druga tendencja opiera się na docenieniu kultur regionalnych, lokalnych, małych ojczyzn, a

szukanie w globalnej wiosce małej ojczyzny, tożsamości i podmiotowości rodzi [ponadto - E.B.] inny stosunek do języka - język jest wówczas traktowany nie tylko jako środek komunikacji, ale funkcjonuje jako istotny znak więzi. Odwołanie się do wartości języka i uznanie go za istotny element identyfikacji to sposób na przeciwstawianie się homogenizacji ogromnych obszarów rzeczywistości symbolicznej, sposób na wyodrębnienie się z tłumu, na ugruntowanie świadomości własnej odrębności kulturowej (Skudrzyk, Urban 2010, 9).

Przeprowadzone badania zdają się potwierdzać, że młodzi ludzie u progu dorosłości dostrzegają w języku właśnie opisywany znak więzi.

\section{Literatura}

Babbie E., 2004, Badania społecそne w praktyce, Warszawa.

Bańkowska E., Mikołajczuk A., red., 2000, Praktyczna stylistyka nie tylko dla polonistów, Warszawa.

Baran L., 2013, Tożsamość narodowa Polaków w przekazach „Naszego Dziennika” i „Gazety Wyborczej” w tygodniu żatoby narodowej po katastrofie smoleńskiej, „Zeszyty Naukowe - Politechnika Śląska. Organizacja i Zarządzanie", z. 65.

Bartmiński J., 2014, Jezyke w kontekśscie kultury, w: Bartmiński J., red., Współcz̧esny jezyk polski, Lublin.

Bartmiński J., Panasiuk J., 1993, Stereotypy jezykowe, w: Bartmiński J., red., Współcz̧esny jezyk polski, Wrocław.

Bokszański Z., 1999, Tożsamość aktora spotecznego a żmiana społeçna, w: Kurczewska J., red., Zmiana społeczna. Teorie i doświadczenia polskie, Warszawa.

Bokszański Z., Piotrowski A., Ziółkowski M., 1977, Socjologia jezykea, Warszawa.

Chlebda W., 1995, Fatum i nadzieja. Szkice do obrazu samoświadomości jezykowej dzisiejszych Rosjan, Opole.

Cybal-Michalska A., 2006, Tożsamość mtodzieży w perspektywie globalnego świata. Studium socjopedagogiczne, Poznań.

Denzin N.K., Lincoln Y.S., 2009, Wprowadžnia. Driedzina i praktyka badań jakościomych, w: Podemski K., red., Metody badań jakościonych, t. 1, Warszawa. 
Dionne E.J., Jr., 2001, Wyzwoliciel czy dyketator. Globalizacja, „Newsweek Polska”, nr 16-17.

Edwards J., 2009, Language and Identity: Key Topics in Sociolinguistics, New York.

Gadamer H.G., 1976, Cžtowiek i jezyk, przeł. K. Michalski, „Teksty”, nr 6.

Giddens A., 2007, Socjologia, przeł. Szulżycka A., Warszawa.

Grzegorczykowa R., 2007, W stęp do jezykoznawstwa, Warszawa.

Grzybowski P., 2001, Tożsamość globalna - kłopoty z poszukiwaniem siebie, w: Bajkowski T., Sawicki K., red., Tożsamość osobowa a tożsamości społeczne, Białystok.

Jawłowska A., 2001, Tożsamość na sprzedaż, w: Jawłowska A., red., Wokół problemów to ̇̇samości, Warszawa.

Jaworska D., 2012, Tożsamość narodowa na pograniczu. Poczucie tożsamości narodowej w narracjach uczniów, rodzicón i nauczycieli polskich szkót na Litwie, Toruń.

Kajtoch W., 2000, Rola jezyka w ksz̨attowaniu poczucia tożsamości subkultur mtodzieżowych, w: Kostyrko T., Zgółka T., red., Kultura wobec kregón tożsamości, Poznań-Wrocław.

Kałuzińska E., 2017, Tożsamość w kontekśsie zmian cywilizacyjnych. Przybliżenia, w: Пасичник И.А., рэА., Наукові записки Начіонального університету „Острозька академія”. Серія: Культурологіа, Випуск 18, Проблеми культурної ідентичності в ситуачї сучасного діалогу культур, Острог.

Karkowska M., 2013, Tożsamość mtodzieży polskiej na prz̨ełomie wieków w perspektymie badań fenomenologicznych. Wyzunania wspótczesności, Lódź.

Kłoskowska A., 1992, Tożsamość $i$ identyfikacja narodowa w perspektywie bistorycznej i psychologicznej, „Kultura i Społeczeństwo”, nr 1.

Konieczna D., 2014, Analiz̧a dyskursu. W poszukiwaniu tożsamości wspótcz̨esnej młodzৃieży, Warszawa.

Kornacka-Skwara E., 2011, Tożsamosí narodowa w swietle przemian kulturowych, „Prace Naukowe Akademii im. Jana Długosza w Częstochowie. Pedagogika”, t. 20.

Krok E., 2015, Budowa kwestionariusza ankietowego a wyniki badań, „Zeszyty Naukowe Uniwersytetu Szczecińskiego. Studia Informatica", nr 37.

Kuczkiewicz-Fraś A., 2012, Jezy/k jako determinant to ̇̇samości narodowej i państwowej w Pakistanie i Bangladeszu, „Politeja”, nr 2/2 (20/2).

Lubas-Bartoszyńska R., 2003, Tożsamość i autobiografia, „Przestrzenie Teorii”, nr 2.

Lubaś W., 2009, Polityka jezylkowa, Opole.

Misiuda-Rewera W., 2016, W stęp. Tożsamość jezykowa i kulturowa, w: Misiuda-Rewera W., Jezyke mniejszości i migracje w pejzażu kulturowym Wtoch, Lublin.

Nowicka E., 1992, Elementy tożsamości społecznej polskiej młodzieży, „Kultura i Społeczeństwo”, nr 4.

Przyszczypkowski K., 1998, Postawy obywatelskie Polaków. Studium empiryczne, w: Melosik Z., Przyszczypkowski K., red., Wychowanie obywatelskie. Studium teoretyczne, porównawcze i empiryczne, Poznań-Toruń.

Rosner K., 1999, Narracja jako struktura rozumienia, „Teksty Drugie”, nr 3.

Rosner K., 2006, Narracja, to żsamość i ças, Kraków.

Skudrzyk A., Urban K., 2000, Maly stownik terminów z zakresu socjolingwistyki i pragmatyki jezykowej, Kraków-Warszawa.

Skudrzyk A., Urban K., 2010, Małe ojczyzny. Świadomość jezylkowo-kulturowa społeçności lokalnych, Katowice.

Szacki J., 2004, O tożsamości (zwłasz̨rza narodowej), „Kultura i Społeczeństwo”, nr 3. 
Szpociński A., 1999, Inni wśród swoich. Kultury artystyczne innych narodów w kulturze Polaków, Warszawa.

Szpociński A., 2000, Tożsamość narodowa w perspektywie kulturalistycznej, w: Kostyrko T., Zgółka T., red., Kultura wobec kregów tożsamości, Poznań-Wrocław.

Tambor J., 2010, Kulturowe wyznaczniki tożsamości. Tożsamość miesžkańcón wojewódætwa ślaskiego, http://www.regionalneobserwatoriumkultury.pl/ [dostęp: 12.08.2014].

Therborn G., 1998, Drogi do nowoczesnej Europy, przeł. Pucek Z., Warszawa-Kraków.

Walczak B., 2013, Jezyk i wyz̧nanie a tożsamość etniçna i narodowa dawniej i džis, w: Cyran G., Skorupska-Raczyńska E., red., Jezy/kowa kreacja tożsamości, Gorzów Wielkopolski.

Warchala J., Skudrzyk A., 2010, Kultura piśmienności młodego pokolenia, Katowice.

Witkowski L., 2000, Rozwój i tożsamość w ykklu sycia. Studium koncepcji Erika H. Eriksona, Torun.

Zinken J., 2015, Lubelska szkoła etnolingwistyczna a anglo-amerykanskie jezykoznawstwo kognitywne, „Etnolingwistyka”, nr 17. 